\title{
Sensibilidad y especificidad de pruebas moleculares en odontología.
}

\author{
Sensitivity and specificity of molecular tests in dentistry.
}

\author{
Daniela Sánchez Feijóo,* Carlos Andrade Tacuri, ${ }^{\ddagger}$ Katherine Cuenca León, ${ }^{\S}$ Paola Orellana Bravoף
}

\section{RESUMEN}

La biología molecular tiene mayor afinidad en las áreas de la salud, en odontología su principal aplicación ha sido en la identificación de microorganismos orales patógenos mediante el uso de secuencias genéticas específicas (ácido desoxirribonucleico [DNA], ácido ribonucleico [RNA] y proteínas). Las pruebas a nivel molecular se caracterizan por su rapidez, reproductibilidad, sensibilidad y especificidad de los microorganismos diana. El presente artículo de revisión bibliográfica servirá como herramienta para comprender los principios de las técnicas más destacadas como son: PCR estándar y RT-PCR en tiempo real, PCR con transcriptasa inversa, microarreglos y ensayo por inmunoabsorción ligado a enzimas (ELISA), además de sus ventajas y desventajas respecto a las pruebas convencionales.

Palabras clave: Biología molecular, sensibilidad y especificidad, técnicas de diagnóstico, odontología.

\section{ABSTRACT}

Molecular biology has a greater affinity in the areas of health. In dentistry, its main application has been the identification of pathogenic oral microorganisms, through the use of specific genetic sequences (deoxyribonucleic acid [DNA], ribonucleic acid [RNA] and proteins). Molecular tests are characterized by their rapidity, reproducibility, sensitivity and specificity of target microorganisms. This literature review article will serve as a tool to understand the principles of the most prominent techniques such as: Standard PCR, Real-time RT-PCR, Reverse transcriptase PCR, microarrays and Enzyme-linked immunosorbent assay (ELISA), in addition to their advantages and disadvantages with respect to conventional tests.

Keywords: Molecular biology, sensitivity and specificity, diagnostic techniques, dentistry.

\section{INTRODUCCIÓN}

L a historia de la biología molecular inició en 1869 con el descubrimiento de su principal macromolécula DNA (ácido desoxirribonucleico) por el biólogo suizo Johan F. Miescher, lo cual dio lugar a nuevas investigaciones. ${ }^{1}$
La biología molecular abrió horizontes a las nuevas generaciones científicas al estudiar los procesos e interacciones de los seres vivos a nivel molecular, esencialmente de DNA, RNA y proteínas, con lo cual se han desarrollado pruebas específicas para el estudio de cada una. ${ }^{2,3}$

A finales del siglo XX las pruebas moleculares se introdujeron al campo odontológico, la primera fue la reacción

\footnotetext{
* Estudiante de la Carrera de Odontología.

‡ MSc. en Biotecnología Molecular. Docente Investigador de la Unidad Académica de Salud y Bienestar.

$\S$ Mgs. en Gerencia en Salud para el Desarrollo Local. Mgs. en Análisis y Diagnóstico de Laboratorio. Docente Investigador de la Unidad Académica de Salud y Bienestar.

ๆ MSc. en Biotecnología. Unidad Académica de Salud y Bienestar. Carrera de Odontología. Laboratorio de Genética y Biología Molecular del Centro de Investigación Innovación y Transferencia de Tecnología.

Universidad Católica de Cuenca. Cuenca-Ecuador.

Recibido: 05 de febrero de 2021. Aceptado: 21 de marzo de 2021.

Citar como: Sánchez FD, Andrade TC, Cuenca LK, Orellana BP. Sensibilidad y especificidad de pruebas moleculares en odontología. Rev ADM. 2021; 78 (2): 90-94. https://dx.doi.org/10.35366/99284
}

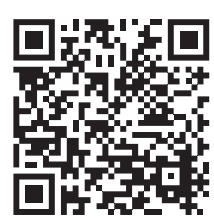


en cadena de la polimerasa (PCR estándar), desarrollada por el bioquímico Kary B. Mullis en el año 1980 mediante el uso forense en 1992 con la identificación de DNA en la pulpa dental humana. Éstas constituyen la respuesta a la necesidad de pruebas sensibles (70-99\%), específicas (86-100\%) y rápidas (1-4 horas) que ayuden con el diagnóstico, control y tratamiento de las patologías orales. Además, logran identificar nuevos microorganismos en la cavidad bucal, responsables de numerosas patologías orales y sistémicas que no habían sido identificadas por métodos microbiológicos. ${ }^{1-5}$

Las técnicas moleculares que serán objeto de esta revisión estudian DNA, RNA y proteínas, y se incluirán: PCR estándar, RT-PCR en tiempo real, PCR transcriptasa inversa, ELISA y microarreglos.

\section{SENSIBILIDAD Y ESPECIFICIDAD DE PRUEBAS MOLECULARES EN ODONTOLOGÍA}

\section{Reacción en cadena de la polimerasa (PCR estándar)}

La técnica PCR (polymerase chain reaction) se basa en un proceso de amplificación selectiva de un segmento de DNA a partir (teóricamente) de una sola copia de la especie diana original, es decir, sólo se necesita $0.1 \mu \mathrm{L}$ de muestra para obtener millones de copias y lograr una identificación certera de linajes, serotipos y mutaciones. La revelación de los resultados se realiza en gel de agarosa o poliacrilamida y hoy en día es usada en diversas especialidades odontológicas por su versatilidad, sensibilidad y precisión. ${ }^{1-4,6,7}$

\section{Sensibilidad y especificidad de la PCR estándar}

La sensibilidad de la PCR estándar es evidenciada durante la amplificación, se usa una porción baja de material genético (DNA) y después de 20 a 40 ciclos se observa la presencia o no de la secuencia buscada. En diversos estudios se ha comprobado su efectividad para la identificación de patógenos bucales como T. forsythia (80\%), P. micra (77.5\%), T. denticola (77.5\%). $1,5,8$

La especificidad es la capacidad que tiene la PCR estándar para identificar microorganismos con alta certeza, pues los cebadores bien diseñados se unirán únicamente a la secuencia de DNA buscada. A esto se debe su alta precisión (95\%) que destaca en el área periodontal. En el caso de S. mutans se comprobó especificidad de $88.2 \%$. 2,8,9

\section{Ventajas}

- Mayor sensibilidad que los procedimientos convencionales. ${ }^{2,5}$

- Análisis rápido y muy versátil. 2,7

- Costo relativamente bajo. ${ }^{5}$

\section{Desventajas}

- Necesidad de un técnico con experiencia. ${ }^{2,7}$

- Identifica presencia o ausencia de una secuencia conocida. ${ }^{10}$

- Propensa a errores por contaminación de reactivos. ${ }^{2-7}$

\section{Reacción en cadena de la polimerasa en tiempo real (qPCR)}

La qPCR (quantitative PCR) se basa en la PCR estándar, utiliza sondas fluorescentes para detectar y cuantificar la presencia de una secuencia específica de las macromoléculas (DNA y RNA) de la muestra. Es muy sensible y específica, consiguiendo amplificar fragmentos de DNA desde 60 pb (par de bases), por lo que permite el diagnóstico de patógenos orales y patologías genéticas. 3,6,11,12

\section{Sensibilidad y especificidad de la qPCR}

La sensibilidad de la qPCR (93-100\%) permite identificar desde un número reducido de células de un agente patógeno que se encuentran en una muestra pequeña la secuencia de DNA blanco. De acuerdo con las investigaciones realizadas con qPCR en odontología, se observaron los siguientes resultados: A. actinomycetemcomitans (87-97\%), P. gingivalis (94-99\%), P. intermedia (93.8\%), M. micros (100\%). ${ }^{12-14}$

En lo que respecta a la especificidad, la técnica demostró ser altamente precisa en la identificación de patógenos, de los cuales destacan el S. mutans (98\%), P. gingivalis (93.3\%), T. denticola (100\%), T. forsythia $(100 \%)$, P. intermedia (80\%), A. actinomycetemcomitans $(89.6 \%) .{ }^{13,15}$

\section{Ventajas}

- Mayor sensibilidad y rapidez en la observación de resultados. ${ }^{4}$

- Precisa en la identificación de los fragmentos de DNA o RNA. ${ }^{14}$

- Cuantificación del producto en tiempo real.,15 


\section{Desventajas}

- Costo elevado de equipos para implementación del laboratorio. ${ }^{4}$

- En caso de RNA es necesario primero obtener DNAc (complementario). ${ }^{16}$

\section{Reacción en cadena de la polimerasa con transcriptasa inversa (RT-PCR)}

La RT-PCR permite amplificar una hebra de ácido ribonucleico (RNA), se crea un molde inicial o plantilla y se combina con PCR usando una transcriptasa inversa para convertir de RNA a DNAc, de esta forma se crean millones de copias para el diagnóstico de muchas patologías orales como caries, infecciones endodóncicas, enfermedades periodontales y cáncer. ${ }^{4-6}$

\section{Sensibilidad y especificidad de la RT-PCR}

La sensibilidad de RT-PCR (89\%) permite obtener suficiente producto con base en cantidades limitadas de material, necesita de $10^{4}$ a $10^{5}$ de células mononucleares dependiendo del tipo y zona de la muestra salival. ${ }^{17}$

La especificidad es considerada alta, pues la técnica realiza amplificación específica del producto que se ha seleccionado, se encuentra cercana al $100 \% .{ }^{17}$

\section{Ventajas}

- Evaluación fácil. ${ }^{17}$

- Bajos costos. ${ }^{17}$

- Alta detección de patógenos. ${ }^{17}$

\section{Desventajas}

- Personal capacitado para la toma de la muestra. ${ }^{17,18}$

- Condiciones de frío precisas. ${ }^{18}$

- Fácil degradación del RNA durante la manipulación. ${ }^{19}$

\section{Microarreglos (microarrays)}

Los microarreglos se caracterizan por combinar dos métodos: el molecular con sondas de DNA y la tecnología de biochips, este proceso consiste en que una micromatriz (chip), que contiene en cada punto una cantidad muy pequeña de sondas específicas de RNA o DNAc, está diseñada para ser complementaria a los segmentos de uno o más genomas de los organismos diana, la identificación del DNA o RNA se logra mediante fluorescencia. ${ }^{7,20}$
La principal característica de los microarreglos es que pueden contener una gran cantidad de sondas $(60,000-$ $100,000)$ y en odontología son útiles en el diagnóstico de microorganismos presentes en la cavidad oral. 7,20,21

\section{Sensibilidad y especificidad de los microarreglos}

La sensibilidad de los microarreglos (96\%) se demostró en el estudio de diversas bacterias como E. faecalis, S. aureus, S. pneumoniae y S. pyogenes. ${ }^{21}$

La especificidad de la prueba (98\%) se basa en la complementariedad de los oligonucleótidos adheridos a la matriz con los de la muestra. Además, tiene la capacidad de detección de un solo microorganismo o de numerosas especies distintas. ${ }^{21,22}$

\section{Ventajas}

- Detección simultánea de varios genomas. ${ }^{7}$

- Menor contaminación de la muestra. ${ }^{22}$

- Elevada sensibilidad y especificidad. ${ }^{23}$

\section{Desventajas}

- Coste relativamente elevado. ${ }^{24}$

- Mayor tiempo de preparación de la sonda. ${ }^{21}$

- Puede ocurrir hibridación cruzada. ${ }^{21}$

\section{Ensayo por inmunoabsorción ligado a enzimas (ELISA)}

La prueba ELISA (enzyme-linked immunosorbent assay) es un ensayo inmunoenzimático que se basa en la unión de anticuerpos que detectan antígenos específicos y mediante un marcador fluorescente de tipo primario (inmunofluorescencia directa) o secundario (inmunofluorescencia indirecta) generan una reacción colorimétrica catalizada por una enzima (fosfatasa alcalina) enlazada al anticuerpo secundario. En odontología es utilizado principalmente como marcador serológico periodontal en la evaluación del riesgo de caries mediante muestras de saliva y en biofilm de la placa dental. ${ }^{22,23}$

\section{Sensibilidad y especificidad de ELISA}

Se ha demostrado que la prueba ELISA logra detectar cantidades muy pequeñas de antígenos en una muestra con ayuda de los fluorogénicos, tiene una sensibilidad de 
$71 \%$ y también cuantifica la cantidad de proteína gtf-B (gene coding for glucosyltransferase). ${ }^{25-27}$

La especificidad de la prueba es de $90 \%$ al identificar diferencias de composición en mezclas complejas como los agentes patógenos que se encuentran en la periodontitis, al igual que determinar $S$. mutans gtf- $B$ sin ser afectado por ningún otro componente. ${ }^{22,26}$

\section{Ventajas}

- Detección en concentraciones muy bajas. ${ }^{22}$

- Es económica. ${ }^{25}$

- Elimina la necesidad de purificar la mezcla. ${ }^{22}$

\section{Desventajas}

- Puede dar falsos positivos. ${ }^{26}$

- Sólo detecta especies que tengan anticuerpos disponibles en kits comerciales. ${ }^{25}$

- Posibilidad de una unión no específica del antígeno. ${ }^{2}$

\section{CONCLUSIÓN}

La implementación de las pruebas moleculares representa un gran avance en el área odontológica por diagnosticar e identificar de manera exitosa los microorganismos patógenos de la cavidad oral. Las pruebas analizadas en esta revisión tienen una alta especificidad y sensibilidad (87-99\%), son efectivas en las diferentes especialidades estomatológicas, sobre todo en periodoncia y cáncer oral.

En odontología las pruebas moleculares son una alternativa prometedora en comparación a las pruebas tradicionales o de cultivo, debido a que la muestra biológica es la saliva que tiene un alto contenido de material genético. A pesar de las limitaciones mencionadas, estas pruebas han demostrado ser muy eficaces en la identificación de agentes patógenos.

\section{REFERENCIAS}

1. Farfán M. Biología molecular aplicada al diagnóstico clínico. Rev Med. Clin. Condes. 2015; 26 (6): 788-793.

2. Rojas L, Gutiérrez R. Reacción en cadena de la polimerasa (PCR) vs. Métodos convencionales en el diagnóstico oportuno de la enfermedad periodontal. Revisión de Literatura. Rev Venez Invest Odont IADR. 2020; 8 (1): 75-104.

3. Alvez M, Lima R, Cavalcanti L, Eleuterio P. Principles and applications of polymerase chain reaction in medical diagnostic fields: a review. Rev. Braz J Microbiol. 2009; 40 (1): 1-11.

4. Romero Y, Díaz A, Arroyo B, Villalba V. Métodos de identificación bacteriana y sus aplicaciones en la investigación odontológica. Duazary. 2010; 7 (2): 247-256.
5. Santos C, Sakai V, Machado M, Schippers D. Reverse transcription and polymerase chain reaction: principles and applications in dentistry. J Appl Oral Sci. 2004; 12 (1): 1-11.

6. Merchán M, Torres M, Díaz A. Molecular biology techniques for research development. A literature review. Rev Haban Cienc Méd. 2017; 16 (5): 796-807.

7. Perea E. La flora de la boca en la era de la biología molecular. Med Oral Patol Oral Cir Bucal. 2004; 9 (1): 1-10.

8. Yarzábal L, Buela L, Djabayan P. Técnicas de biología molecular para la investigación en odontología y biología oral (1a parte). Revista OACTIVA UC Cuenca. 2018; 3 (1): 29-36.

9. Al-hebshi N, Al-Alimi A, Taiyeb-Ali T, Jaafar N. Quantitative analysis of classical and new putative periodontal pathogens in subgingival biofilm: a case-control study. J Periodontal Res. 2015; 50 (3): 320329.

10. Salazar A. Vásquez C, Almuna A, Oporto G. Detección Molecular de Estreptococos Cariogénicos en Saliva. Int J Morphol. 2008; 26 (4): 951-958.

11. Moncada G, Duperat L, Palma P, Corsini G. Técnica de reacción de polimerasa en cadena (qPCR) en tiempo real para la identificación y cuantificación de Streptococcus mutans en saliva y biopelícula dentaria de niños. Rev Fac Odontol Univ Antioq. 2016; 28 (1): 71-94.

12. Vinueza C. PCR en tiempo real: la nueva era de la información genética celular. REDVET. 2009; 10 (2): 1-13.

13. Boutaga K, Savelkoul P, Winkel E, Van Winkelhoff A. Comparison of subgingival bacterial sampling with oral lavage for detection and quantification of periodontal pathogens by real-time polymerase chain reaction. J Periodontol. 2007; 78 (1): 79-86.

14. Atieh M. Accuracy of real-time polymerase chain reaction versus anaerobic culture in detection of Aggregatibacter actinomycetemcomitans and Porphyromonas gingivalis: a metaanalysis. J Periodontol. 2008; 79 (9): 1620-1629.

15. Kotsilkov K, Popova C, Boyanova L, Setchanova L. Comparison of culture method and real-time PCR for detection of putative periodontopathogenic bacteria in deep periodontal pockets. Biotechnology \& Biotechnological Equipment. 2015; 29 (5): 9961002.

16. Domínguez J, Blanco S, Lacoma A, García N. Utilidad de la biología molecular en el diagnostico microbiológico de las infecciones por micobacterias. Enferm Infecc Microbiol Clin. 2008; 26 (9): 33-41.

17. Parada F, Fonseca D, Carvajal M, Sepulveda C. Comparación de la muestra salival y de nasofaringe en la detección de SARS-CoV-2 mediante RT-PCR. Int J Odontostomat. 2020; 14 (4): 540-543.

18. Polony M, Prenninger $\mathrm{N}$, Arweiler $\mathrm{N}$, Haririan $\mathrm{H}$, Winklehner P. Assessment of viable periodontal pathogens by reverse transcription quantitative polymerase chain reaction. J Periodont Res. 2013; 48 (1): 671-676.

19. Díaz C, Garrote H, Amor A, Suarez Y. Cuantificación de ácido ribonucleico para la realización de la técnica de RT-PCR. Rev Cubana Hematol Inmunol Hemoter. 2013; 29 (3): 298-303.

20. Bridge J. Reverse transcription-polymerase chain reaction molecular testing of cytology specimens: Pre-analytic and analytic factors. Cancer Cytopathol. 2017; 125 (1): 11-19.

21. Donatin E, Drancourt M. DNA microarrays for the diagnosis of infectious diseases. Med Mal Infect.2012; 42 (1): 453-459.

22. Gupta S, Bains V, Jhingran R, Madan R. Microarray: an emerging diagnostic tool in dentistry. AJOHAS. 2012; 2 (2): 78-83.

23. Herrera H, Gancino M. DNA microarrays: recent Advances. Bionatura. 2017; 2 (3): 404-406.

24. McLoughlin K. Microarrays for pa pathogen detection and analysis. Brief Funct Genomics. 2011; 10 (6): 342-353M. 
25. Gan S, Patel K. Enzyme immunoassay and enzyme-linked immunosorbent Assay. J Invest. Dermatol. 2013; 133 (9): 1-3.

26. Shinozaki N, Hashizume T, Hirasawa M, Takada K. A feasible enzymelinked immunosorbent assay system using monoclonal and polyclonal antibodies against glucosyltransferase-B from Streptococcus mutans. Hybridoma (Larchmt). 2012; 31 (3): 176-179.

27. Pussinen P, Vilkuna T, Alfthan G, Mattila K. Multiserotype enzymelinked immunosorbent assay as a diagnostic aid for periodontitis in large-scale studies. J Clin Microbiol. 2002; 40 (2): 512-518.
Correspondencia:

Est. Daniela Sánchez Feijóo

E-mail: dfsanchezf53@est.ucacue.edu.ec

Conflicto de intereses: Los autores declaran no tener ningún conflicto de intereses.

Aspectos éticos: Ninguno.

Financiamiento: Ninguno. 